\title{
MONITORING OF EXPERIMENTALLY INDUCED HYPERLIPIDAEMIA IN DONKEYS
}

\author{
A.G.A. BULLDAN*; H.I. SERI**; S.E. SULIMAN ${ }^{* *}$ and G.E. MOHAMMED** \\ ${ }^{*}$ Faculty of Veterinary Science, University of West Kordofan, Sudan. \\ ** College of Veterinary Medicine, Sudan University of Science and Technology. \\ Correspondence author: Hisham Ismail Seri E-mail: hishamseri@sustech.edu
}

\section{ABSTRACT}

Received at: $29 / 6 / 2013$

Accepted: $16 / 7 / 2013$
Controlled experiment was conducted to induce hyperlipidaemia in donkeys. For the purpose of the study, 12 male donkeys 4-10 years were housed in the College farm in different pens. Animals were randomly allocated into two groups of equal number. Animals in the two groups were subjected to fasting for 4 and 5 days, respectively. Blood samples were collected several times during three occasions i.e. pre-fasting, fasting and post fasting. Haemoglobin concentration, packed cell volume and RBCs count were evaluated in all animals. Plasma was tested for total proteins, albumin, triglycerides (TG), total cholesterol, urea, creatinine, AST activity level and Bilirubin. Pulse rate, respiratory rate and rectal temperature were also evaluated. General health of animals and abnormal clinical signs were recorded daily. Withholding feed significantly increased mean plasma urea, AST, bilirubin and creatinine level. Total protein and albumin, decreased significantly in animals subjected to fasting for five days, compared with baseline values. Mean plasma TG and total cholesterol concentrations significantly increased with time in feed-deprived donkeys. In conclusion, withholding feed for four and five days significantly increases blood lipid concentrations in donkeys, but individual donkeys respond differently.

Keywords: Hyperlipidaemia, withholding offeed, donkeys, Sudan

\section{INTRODUCTION}

Disturbances of lipid metabolism that result in accumulation of triglycerides in the blood are common in equine species (Gay et al., 1978; Naylor et al., 1980; Jeffcott and Field, 1985a; Watson et al., 1992a and Watson and love, 1994). Hyperlipaemia is a pathophysiological response to prolonged negative energy balance associated with gross lipaemia (Naylor et al., 1980; Watson et al., 1992a; Watson and love, 1994). Hyperlipaemia in equine has been thoroughly reviewed elsewhere (Watson, 1994; Hughes et al., 2004; Mckenzie, 2011).

Hyperlipaemia is a life-threatening condition in horses, ponies, and donkeys (Moore et al., 1994, Mogg and Palmer, 1995; Dunkel and McKenzie, 2003, Hughes et al., 2004). If left undetected or untreated, hyperlipaemia may progress to hepatic lipidosis and liver failure with multi-systemic complications (Mogg and Palmer, 1995). The disease is well described in donkeys (Naylor et al., 1980; Mair, 1995) with mortality from $86 \%$ to $95 \%$, higher than that in ponies (Fowler, 1989).

Suggested predisposing factors include food deprivation or increased metabolic demands, most remarkably in obese ponies, American Miniature Horses, or donkeys (Naylor et al., 1980; Moore et al., 1994; Mogg and Palmer, 1995; Frank et al., 2002; Dunkel and McKenzie, 2003; Hughes et al., 2004).

Various risk factors for the development of hyperlipaemia have been reported; the disease is most common in mares of all breeds, accounting for between 74 and 100\% of affected horses (Gay et al., 1978 and Watson et al., 1992a). Reproductive activity appears to increase the susceptibility of pony mares to hyperlipaemia, with late pregnancy and early lactation being predisposing factors (Gay et al., 1978; Jeffcott and Field 1985a \&b; Watson et al., 1992a). Reproductive activity does not appear to be a strong predisposing factor in miniature breeds, with $65-71 \%$ of affected females reproductively inactive (Moore et al., 1994 and Mogg and Palmer, 1995).

The condition tends to occur in middle-aged, obese donkeys often secondary to an episode of stress (Whitehead et al., 1991). Typically identified stressors include debilitating malaise such as laminitis or parasitism, nutritional deprivation and behavioural stress. Higher incidence of hyperlipaemia, were associated with lactation or late 
gestation in Ponies (Jeffcott and Field, 1985a and Schotmann and Kroneman, 1969).

In ponies and donkeys hyperlipaemia is usually a primary disease process, and stress and obesity appear to be particularly important predisposing factors (Jeffcott and Field, 1985b; Watson et al., 1992a and Mair, 1995). Food deprivation, either accidental, intentional, or relative to the increased metabolic demands of pregnancy or lactation; is a common predisposing factor in primary and secondary hyperlipaemia (Gay et al., 1978; Jeffcott and Field, 1985b; Moore et al., 1994 and Mogg and Palmer, 1995).

Few detailed case studies in the donkey have been reported, and all have come from the northern hemisphere (Rognerud, 1976; Bossche and VandenBossche, 1988; Mair, 1995). One report from Australia (Tarrant et al., 1998) described hyperlipaemia in a 10 year-old, multiparous, female Jerusalem donkey.

The objective of the current study is to monitor clinical changes in experimentally induced hyperlipidaemia in donkeys due to withholding of feed.

\section{MATERIALS and METHODS}

Site of study: The study was carried at the farm of the College of Veterinary Medicine, Sudan University of Science and Technology (SUST), East Nile locality, Hillat Kuku, Sudan.

Ethical approval: The study protocol was approved by the College of Veterinary Medicine Research Board as well as the Deanship of Scientific Research, Sudan University of Science and Technology.

Experimental animals: Twelve male donkeys 4-10 years of age were purchased from local market. Upon their arrival animals were subjected to thorough clinical examination and received antibiotic and anthelmintics. Following adaption period of 10 days, animals were randomly assigned to two groups each of six. Animals in the first group were subjected to fasting for four days, and animals in the second group were subjected to fasting for five days. Water was provided for ad libitum intake.

Blood samples: Seven $\mathrm{ml}$ of blood were collected at predetermined time points during three different occasions i.e. pre-fasting (three samples), fasting (3-4 samples) and post-fasting (three samples), via jugular vein puncture into EDTA-coated tubes. Blood was collected between 08:30 and 09:30 AM and kept immediately in ice for transport to the laboratory. Haematological parameters were tested in whole blood while biochemical tests were carried on plasma following centrifugation of whole blood.

Haematological parameters: Haemoglobin, packed cell volume, and total red blood cells count were measured according to Schalm and Jain (1986).

Analysis of Plasma constituents: Concentrations of plasma TG and total cholesterol were measured using the enzymatic colorimetric reagents. Plasma total protein, albumin, urea, creatinine, AST activity level were measured using an in vitro enzymatic colorimetric test kit (Biosystems, S.A. Spain).

Clinical parameters: Pulse rate, respiratory rate and rectal temperature were measured using standard methods (Kelly, 1986).

Statistical analysis: Data were analyzed using GraphPad Prism 5.0 (GraphPad Software). Differences between the three groups were analyzed by using one way ANOVA. The significance is indicated as $* \mathrm{p}<0.05 ; * * \mathrm{p}<0.01$ and $* * * \mathrm{p}<0.001$.

\section{RESULTS}

Clinical signs: the animals showed dullness, depression, nervousness, coprophagia, weakness, signs of colic (abdominal pain, rolling and grinding of teeth), and lethargy.

Physiological parameters: In the second group there was significant $(\mathrm{P}<0.05)$ decrease in respiratory rate in the post-fasting observation period. In the first group there was no significant $(\mathrm{P}>0.05)$ change in respiratory rate. The other parameters tested expressed no significant $(\mathrm{P}>0.05)$ fluctuation within the normal range observed in the pre-fasting period as shown in table (1).

Haemtological parameters: There was significant $(\mathrm{P}<0.05)$ decrease in $\mathrm{PCV}$ and haemoglobin concentration in the second group as shown in table (2).

Biochemical parameters: In the first group there was no significant $(\mathrm{P}>0.05)$ decrease in the total protein concentration during fasting, while the level increased significantly $(\mathrm{P}<0.05)$ following refeeding. In the second group there was significant $(\mathrm{P}<0.05)$ decrease in total protein and albumin concentration during the fasting period (table 3 ).

As shown in table (3) in the first group, it could be observed that there was no significant $(\mathrm{P}>0.05)$ increase in total triglycerides and total cholesterol during the fasting period, while there was significant $(\mathrm{P}<0.05)$ increase during the post fasting period. In the other hand, there was significant $(\mathrm{P}<0.05)$ 


\section{Assiut Vet. Med. J. Vol. 59 No. 138 July 2013}

increase in total triglycerides and total cholesterol concentration in the second group during fasting period.

In the first group, urea, AST activity level, bilirubin and creatinine level increased significantly during the fasting period. Bilirubin and creatinine continued to increase significantly at post fasting. In the second group, Urea, AST and bilirubin exhibited non significant change, While, creatinine showed significant increase during the fasting period (table 3).

Table 1: Effect of fasting on physiological parameters

\begin{tabular}{lcccccccc}
\hline \multirow{2}{*}{ Parameters } & \multicolumn{4}{c}{ Four days fasting } & & \multicolumn{3}{c}{ Five days fasting } \\
\cline { 2 - 9 } & Pre-fasting & Fasting & Post-fasting & P-value & Pre-fasting & Fasting & Post-fasting & P-value \\
\hline $\mathrm{RR} / \mathrm{min}$ & $31.17 \pm 4.88$ & $30.33 \pm 6.91$ & $30.67 \pm 2.93$ & 0.8923 & $30.33 \pm 6.91$ & $33.75 \pm 3.53^{*}$ & $30.11 \pm 2.81^{*}$ & 0.0207 \\
\hline $\mathrm{PR} / \mathrm{min}$ & $53.28 \pm 8.74$ & $49.67 \pm 7.32$ & $49.89 \pm 4.44$ & 0.2317 & $49.67 \pm 7.32$ & $52.54 \pm 3.53$ & $50.78 \pm 4.24$ & 0.1955 \\
\hline Temperature ${ }^{\circ} \mathrm{C}$ & $38.21 \pm 1.09$ & $38.01 \pm 0.66$ & $38.11 \pm 0.71$ & 0.7663 & $38.01 \pm 0.66$ & $37.87 \pm 0.50$ & $38.04 \pm 0.61$ & 0.5942 \\
\hline
\end{tabular}

$\mathrm{RR}=$ respiratory rate, $\mathrm{PR}=$ Pulse rate

Table 2: Effect of fasting on haemtological parameters

\begin{tabular}{lcccccccc}
\hline & \multicolumn{4}{c}{ Four days fasting } & \multicolumn{3}{c}{ Five days fasting } \\
\cline { 2 - 8 } Parameters & Pre-fasting & Fasting & Post-fasting & P-value & Pre-fasting & Fasting & Post-fasting & P-value \\
\hline $\mathrm{TRBCs} / \mathrm{mm} 3$ & $7.98 \pm 0.81$ & $7.87 \pm 0.54$ & $8.12 \pm 0.92$ & 0.6113 & $7.87 \pm 0.54$ & $7.80 \pm 0.43$ & $7.66 \pm 0.61$ & 0.4525 \\
\hline $\mathrm{PCV}(\%)$ & $28.17 \pm 3.17$ & $29.50 \pm 2.12$ & $28.61 \pm 1.65$ & 0.2458 & $29.50 \pm 2.12^{\mathrm{a}}$ & $29.88 \pm 2.27^{\mathrm{a}}$ & $27.17 \pm 2,43^{\mathrm{b}}$ & 0.0009 \\
\hline $\mathrm{Hb} \mathrm{g} / \mathrm{dl}$ & $16.39 \pm 2.15$ & $16.28 \pm 1.23$ & $15.11 \pm 1.23$ & 0.0361 & $16.28 \pm 1.23^{\mathrm{a}}$ & $15.21 \pm 1.02^{\mathrm{b}}$ & $14.39 \pm 1.04^{\mathrm{c}}$ & 0.0001 \\
\hline
\end{tabular}

Table 3: Effect of fasting on biochemical parameters

\begin{tabular}{|c|c|c|c|c|c|c|c|c|}
\hline \multirow{2}{*}{ Parameters } & \multicolumn{4}{|c|}{ Four days fasting } & \multicolumn{4}{|c|}{ Five days fasting } \\
\hline & Pre-fasting & Fasting & Post-fasting & P-value & Pre-fasting & Fasting & Post-fasting & P-value \\
\hline Total protein g/l & $60.50 \pm 10.28$ & $57.89 \pm 9.06^{*}$ & $68.50 \pm 12.63 *$ & 0.0128 & $66.78 \pm 5.87^{\mathrm{a}}$ & $56.88 \pm 10.28^{\mathrm{b}}$ & $53.67 \pm 11.44^{\mathrm{b}}$ & 0.0003 \\
\hline Albumin g/l & $21.11 \pm 3.92$ & $20.67 \pm 7.45$ & $22.28 \pm 2.97$ & 0.6283 & $23.61 \pm 3.40^{\mathrm{a}}$ & $22.67 \pm 3.09^{\mathrm{a}}$ & $20.72 \pm 2.95^{\mathrm{b}}$ & 0.0240 \\
\hline $\begin{array}{l}\text { Triglycerides } \\
\mathrm{mmol} / \mathrm{l}\end{array}$ & $0.64 \pm 0.39 *$ & $2.13 \pm 2.13$ & $3.58 \pm 2.77 *$ & 0.0003 & $0.47 \pm 0.33 \mathrm{a}$ & $1.68 \pm 1.68 \mathrm{~b}$ & $1.81 \pm 1.99 b$ & 0.0187 \\
\hline $\begin{array}{l}\text { Cholesterol } \\
\mathrm{mmol} / \mathrm{l}\end{array}$ & $1.53 \pm 0.66^{*}$ & $1.76 \pm 1.76$ & $2.66 \pm 0.84^{*}$ & 0.0154 & $0.89 \pm 0.41 \mathrm{a}$ & $2.14 \pm 1.36 \mathrm{~b}$ & $2.14 \pm 1.17 b$ & 0.0007 \\
\hline Urea mg/dl & $2.96 \pm 0.93 *$ & $4.81 \pm 2.81 *$ & $4.01 \pm 2.13$ & 0.0369 & $5.39 \pm 1.85$ & $6.23 \pm 2.57$ & $5.44 \pm 2.46$ & 0.4267 \\
\hline AST UI & $18.44 \pm 4.55^{*}$ & $28.67 \pm 9.82 *$ & $24.35 \pm 10.44$ & 0.0036 & $5.84 \pm 2.01$ & $6.47 \pm 2.81$ & $5.67 \pm 4.01$ & 0.6638 \\
\hline $\begin{array}{l}\text { Bilirubin } \\
\mathrm{mg} / \mathrm{dl}\end{array}$ & $0.79 \pm 0.68^{\mathrm{a}}$ & $4.87 \pm 4.62^{\mathrm{b}}$ & $5.05 \pm 5.87^{\mathrm{b}}$ & 0.0064 & $1.24 \pm 0.42$ & $1.69 \pm 0.66$ & $2.97 \pm 4.06$ & 0.0666 \\
\hline $\begin{array}{l}\text { Creatinine } \\
\mathrm{mg} / \mathrm{dl}\end{array}$ & $1.24 \pm 0.42$ & $1.58 \pm 0.64 *$ & $1.09 \pm 0.66^{*}$ & 0.0482 & $1.09 \pm 0.66 \mathrm{a}$ & $1.67 \pm 0.59 \mathrm{~b}$ & $1.24 \pm 0.42 \mathrm{a}$ & 0.0035 \\
\hline
\end{tabular}




\section{DISCUSSION}

Given the high mortality associated with hyperlipaemia, it is of considerable importance to veterinarians dealing with susceptible equine populations (Jeffcott and Field, 1985a; Watson and Love, 1994). Hyperlipaemia in the donkey induce mortality from $86 \%$ to $95 \%$ (Fowler, 1989), higher than that in the pony.

Clinical signs monitored in this study are in accordance with that reported by Watson (1994). Here in the present study, there was significant $(\mathrm{P}<0.05)$ decrease in respiratory rate in the postfasting observation period in the second group. The respiratory rate was not below the reference values (26.90土.9.40) for donkeys reported by French, and Patrick, (1995), and Etana and his colleagues (2011).

There was fluctuation (within the normal range) in the values of pulse rate and rectal temperature observed in the pre-fasting period as shown in table (1). Here the values are also within the recommended reference values recommended by other researchers (French, and Patrick, 1995, and Etana et al., 2011).

There was significant $(\mathrm{P}<0.05)$ decrease in $\mathrm{PCV}$ and haemoglobin concentration in the second group (table 2). It could be observed that in the two groups there was no significant $(\mathrm{P}>0.05)$ increase in the $\mathrm{PCV}$ values during fasting, while in post fasting period there was significant $(\mathrm{P}<0.05)$ increase in PCV level. This result is in agreement with that of Tarrant et al. (1998), who reported significant increase in the first day of a 10-year -old, multiparous, female Jerusalem donkey that was presented with a 2-day history of mild depression, in appetence and lethargy. There was increase in PCV $(46 \%)$ in the first day of hospitalization and then the level declined to $(32 \%)$ following 12 days of hospitalization. Physiologically, this result could be justified as the animals decrease the intake of water during fasting which may lead to haemconcentration, and following re-feeding the animals tend to drink water as usual, resulting in haemdilution.

In the first group there was no significant $(\mathrm{P}>0.05)$ decrease in the total protein concentration during fasting, while the level increased significantly following re-feeding. In the second group there was significant decrease in total protein and albumin concentration during the fasting period (table 3 ).

The fluctuation in total protein and albumin concentration could be attributed to haemconcentration, while in the second group the decrease could be attributed to the negative energy balance.
In the first group (table 3), it could be observed that there was no significant $(\mathrm{P}>0.05)$ increase in total triglycerides and total cholesterol during the fasting period, while there was significant increase during the post fasting period. On the other hand, there was significant increase in total triglycerides and total cholesterol concentration in the second group during fasting period. This could be attributed to the non significant $(\mathrm{P}>0.05)$ increase during fasting period in the first group to the fact that most of the animals in this experiment had body score ranging from fair to good.

The plasma total triglyceride concentration measured in the present study remained significantly $(\mathrm{P}<0.05)$ lower than values reported previously, with a range 0.47 $\pm 0.33-3.58 \pm 2.77$. Individual animals showed TG level up to $11.3 \mathrm{mmol} / \mathrm{l}$ in the first group and 8.8 $\mathrm{mmol} / \mathrm{l}$ in the second group during the fasting period. While the primary causes and clinical presentation leading to hypertriglyceridaemia/ hyperlipaemia appear similar among equids, the degree of plasma triglyceride (TG) increase appears to differ substantially. Fasting of healthy animals results in only a moderate increase of plasma total triglyceride. The values reported for fasted health horses $(<2.26$ mmol/1; Naylor et al., 1980) are lower compared to fasted healthy ponies (mean value $8.27 \mathrm{mmol} / 1$, range 0.23-20.34 mmol/1; Bauer, 1983) and fasted health donkeys (4.24 $\pm 0.56 \mathrm{mmol} / \mathrm{l}$; Forhead et al., 1994).

In naturally occurring hyperlipaemia, the elevation of total triglycerides exceeds the values obtained from fasting normal animals (Dunkel and Mckenzie, 2003). Reported mean \pm SD of total triglycerides (TG) levels reached $25.4 \pm 18.1 \mathrm{mmol} / 1$ in ponies (range 4.69-79.1 mmol/1; Watson et al., 1992a), 14.92 $\mathrm{mmol} / \mathrm{l}$ in miniature horses (range 5.57-31.98 mmol/l; Mogg and Palmer, 1995), $23.98 \mathrm{mmol} / \mathrm{l}$ in miniature horses and miniature donkeys (range 15.11-33.95 mmol/1; Moore et al., 1994) and 16.6 $\pm 1.9 \mathrm{mmol} / \mathrm{l}$ in donkeys (Forhead et al., 1994).

Total cholesterol level in the study conducted by Tarrant and his colleagues (1998) was higher at the beginning $(7.2 \mathrm{mmol} / \mathrm{l})$ and reduced to $2.1 \mathrm{mmol} / \mathrm{l}$ following hospitalization for 19 days (reference values $2.8 \pm 0.8$ ). Here the level of cholesterol starts to rise during fasting period and continued at higher levels during re-feeding period.

The reasons for the differences noted regarding hypertriglyceridaemia in different types of equids might be related to fundamental differences in energy metabolism and endocrine responses to dietary influences (Dunkel and McKenzie, 2003). Differences in carbohydrate metabolism between ponies and horses have been reported, including 
increased circulating baseline levels of insulin, impaired glucose tolerance (Jeffcott et al., 1986) and increased free fatty acid release from simulated pony adipocytes compared to horse adipocytes (Breidenbach et al., 1999).

In donkeys, with naturally occurring hyperlipidaemia/ hyperlipaemia, a positive correlation between plasma insulin and STG concentration has been reported (Forhead et al., 1994). Activities of lipoprotein lipase and hepatic lipase are higher in hypertriglyceridemic, feeddeprived horses than in fed horses (Frank et al., 2003). This suggests that overproduction of triglycerides, possibly complicated by defective catabolism, is the predominant cause of hypertriglyceridemia (Watson et al., 1992b).

In the first group, urea, AST activity level, total bilirubin and creatinine level increased significantly $(\mathrm{P}<0.05)$ during the fasting period. Bilirubin and creatinine continued to increase significantly at post fasting. In the second group, Urea, AST and bilirubin exhibited non significant $(\mathrm{P}>0.05)$ change, while, creatinine showed significant increase during the fasting period (table 3). Tarrant et al., (1998), reported increase in Urea $(31.2 \mathrm{mg} / \mathrm{dl})$ and decrease in $\operatorname{AST}(270 \mathrm{UI})$.

Azotaemia has been associated with hypertriglyceridaemia in several reports. A statistically significant association has been found between serum creatinine and STG in horses (Naylor et al., 1980) and ponies with hyperlipaemia (Watson et al., 1992a). Eight horses had an elevated serum creatinine (mean $0.46 \mathrm{mmol} / \mathrm{l}$ ) concurrent with peak STG measured; 12 horses had an elevation of the serum creatinine concentration at least once during their hospitalization (Dunkel and McKenzie, 2003).

\section{CONCLUSION}

It is to be concluded that fasting of male donkeys for four and five days (with exclusion of other risk factors), resulted in moderate hyperlipidaemia. Individual variation in the level of total triglycerides was observed within donkeys in relation to body score. Further work was required to test the contribution of other risk factors viz: parasitism, pregnancy and lactation.

\section{ACKNOWLEDGEMENTS}

This work was supported by a grant from the Scientific Research Deanship, Sudan University of Science and Technology. The authors are grateful to Deanship of Scientific Research, Sudan University of
Science and Technology for permission to publish this work.

\section{REFERENCES}

Bauer, J.E. (1983): Plasma lipids and lipoproteins of fasted ponies. Am. J. Vet. Res. 44, 379-384.

Bossche, G.V. and Vanden-Bossche, G. (1988): Cachexia syndrome in a donkey mare as a result of a toxic-infectious enteritis. Berl Munch Tierarzt Wochenschr; 101: 190-193.

Breidenbach, A.; Fuhrmann, H.; Deegen, E.; Lindholm, A. and Sallmann, H.P. (1999): Studies on equine lipid metabolism. 2. Lipolytic activities of plasma and tissue lipases in large horses and ponies. Zentralbl Veterinarmed A. 46(1): 39-48.

Dunkel, B. and McKenzie, H.C. (2003): III. Severe hypertriglyceridaemia in clinically ill horses: diagnosis, treatment and outcome. Equine Vet J; 35: 590-595.

Etana, M.; Endeabu, B.; Jenberie, S. and Negussie, $H$. (2011): Determination of reference physiological values for working donkeys of Ethiopia. Ethiop. Vet. J., 15 (1), 79-86

Forhead, A.J.; French, J.; Ikin, P.; Fowler, J.N. and Dobson, H. (1994): relationship between plasma insulin and triglyceride concentrations in hypertriglyceridaemic donkeys. Res. Vet. Sci. 56, 389-392.

Fowler, J.N. (1989): Medical. In: The professional handbook of the donkey. $2^{\text {nd }}$ ed. The Donkey Sanctuary, Devon: 101-109.

Frank, N.; Sojka, J.E. and Latour, M.A. (2002): Effect of withholding feed on concentration and composition of plasma very low density lipoprotein and serum nonesterified fatty acids in horses. Am. J. Vet. Res. 63(7): 1018-1021.

Frank, N.; Sojka, J.E. and Latour, M.A. (2003): Effects of hypothyroidism and withholding of feed on plasma lipid concentrations, concentration and composition of very-lowdensitiy lipoprotein, and plasma lipase activity in horses. Am. J. Vet. Res. 64: 823-828.

French, J.M. and Patrick, V.H. (1995): Reference values for physiological, hematological and biochemical parameters in domestic donkeys (Equus asinus), Equine Vet. Educ., 7:33-35.

Gay, C.C.; Sullivan, N.D.; Wilkinson, J.S.; McLean, J.D. and Blood, D.C. (1978): Hyperlipaemia in ponies. Aust. Vet. J.; 54: 459-462.

Hughes, K.J.; Hodgson, D.R. and Dart, A.J. (2004): Equine hyperlipaemia: a review. Aust. Vet. J.; 82: 136-142.

Jeffcott, L.B. and Field, J.R. (1985a): Current concepts of hyperlipaemia in horses and ponies. Vet. Rec.; 116: 461-466.

Jeffcott, L.B. and Field, J.R. (1985b): Epidemiological aspects of hyperlipaemia in 
ponies in southeastern Australia. Aust. Vet. J. 62: 140-141.

Jeffcott, L.B.; Field, J.R.; McLean, J.G. and O'Dea, $K$. (1986): Glucose tolerance and insulin sensitivity in ponies and standard bred horses. Equine Vet. J. 18: 97-101.

Kelly, W.R. (1984): Veterinary clinical diagnosis. Bailliere Tindall,London. $3^{\text {rd }}$ edition $.440 \mathrm{pp}$.

Mair, T.S. (1995): Hyperlipaemia and laminitis secondary to an injection abscess in a donkey. Equine Vet. Educ; 7: 8-11.

McKenzie, H.C. $3^{\text {rd }}$ (2011): Equine hyperlipidemias. Vet Clin North Am Equine Pract. 27(1): 59-72.

Mogg, T.D. and Palmer, J.E. (1995): Hyperlipidemia, hyperlipemia, and hepatic lipidosis in American Miniature Horses: 23 cases (1990-1994). J. Am. Vet. Med. Assoc.; 207: 604-607.

Moore, R.B.; Abood, S.K. and Hinchcliff, K.W. (1994): Hyperlipemia in 9 miniature horses and miniature donkeys. J. Vet. Intern. Med.; 8: 376-381.

Naylor, J.M. (1982): Treatment and diagnosis of hyperlipaemia and hyperlipidemia. Proc. Am. Assoc. Equine Pract. 27: 323-328.

Naylor, J.M.; Kronfeld, D.S. and Acland, H. (1980): Hyperlipemia in horses: effects of under nutrition and disease. Am. J. Vet. Res. 41: 899-905.
Rognerud, B. (1976): Hyperlipaemia in ponies. A review and four case histories. Norsk Vet Tidschr; 88: 227-232.

Schalm, O.W. and Jain, N.C. (1986): Veterinary Haematology, $4^{\text {th }}$ ed., Lea and Febiger, Philadelphia.

Schotmann, A.J.H. and Kroneman, J. (1969): Hyperlipaemia in ponies. Neth J. Vet. Sci.; 2: 60-64.

Tarrant, J.M.; Campbell, T.M. and Parry, B.W. (1998): Hyperlipaemia in a donkey. Aust. Vet. J. 76(7): 466-469.

Watson, T.D.; Murphy, D. and Love, S. (1992a): Equine hyperlipaemia in the United Kingdom: clinical features and blood biochemistry of 18 cases. Vet. Rec. 131, 48-51.

Watson, T.D.; Burns, L.; Love, S.; Packard, C.J. and Shepherd, J. (1992b): Plasma lipids, lipoproteins and post-heparin lipases in ponies with hyperlipaemia. Equine Vet J 1992; 24:341-346.

Watson, T.D.G. (1994): Hyperlipaemia in ponies. In Practice, 267-272.

Watson, T.D.G. and Love, S. (1994): Equine hyperlipaemia. Compend. Contin. Educ. Pract. Vet. 16: 89-97.

Whitehead, G.; French, J. and Ikin, P. (1991): Welfare and veterinary care of donkeys. In Practice; 13: 62-68.

\section{مراقبة ارتفاع الدهون المحدث تجريبيا في الحمير}

\footnotetext{
أحمد جعفر أحد بلدان ، هشام اسماعيل سري ، سهام الياس سليمان ، جلال الدين الازهري محمد

أجريت هذه التجربة تحت ظروف سيطرة محددة، لاحداث ارتفاع الدهون تجريبيا في الحمير. من أجل هذا الغرض استخدم T أ من

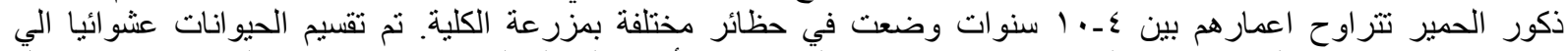

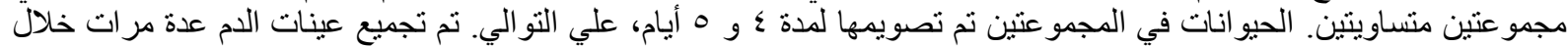

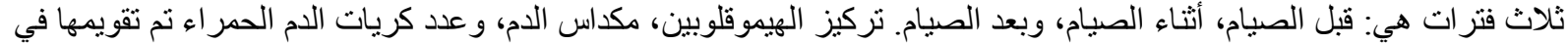

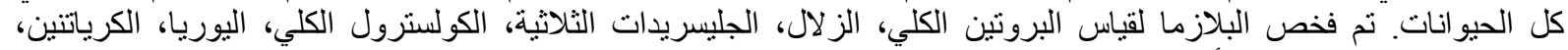

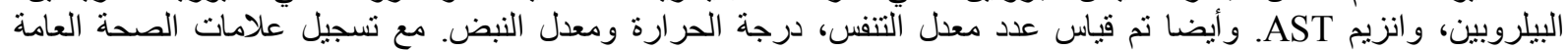

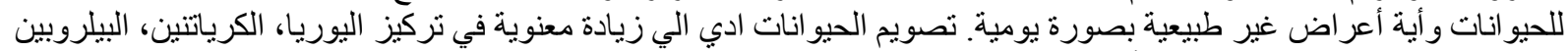

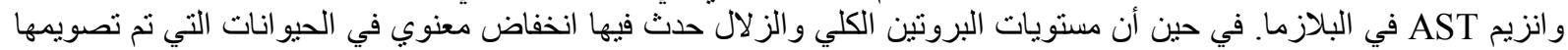

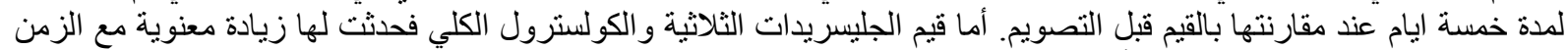

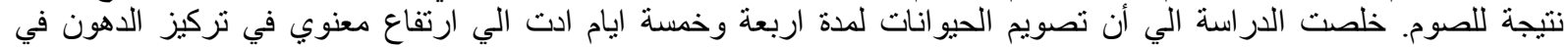
البلازما، ولكن استجابة الحيو انات الفردية للتصويم اظهرت التهرت اختلافا.
} 